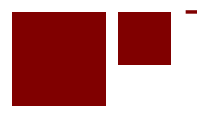

C E N T E R for
RETIREMENT
RE E E A R C H
at BOSTON COLLEG

\title{
A BEHAVIORAL ECONOMICS ASSESSMENT OF SSDI EARNINGS REPORTING DOCUMENTS
}

\author{
Denise Hoffman, Jonah Deutsch, and Britta Seifert
}

CRR WP 2020-15

November 2020
Center for Retirement Research at Boston College
Hovey House
140 Commonwealth Avenue
Chestnut Hill, MA 02467

Tel: 617-552-1762 Fax: 617-552-0191

https://crr.bc.edu

\begin{abstract}
All of the authors are with Mathematica Policy Research. Denise Hoffman and Jonah Deutsch are senior researchers and Britta Seifert is a health analyst. The research reported herein was derived in whole or in part from research activities performed pursuant to a grant from the U.S. Social Security Administration (SSA) funded as part of the Retirement and Disability Research Consortium. The opinions and conclusions expressed are solely those of the authors and do not represent the opinions or policy of SSA, any agency of the federal government, Mathematica Policy Research, or Boston College. Neither the United States Government nor any agency thereof, nor any of their employees, make any warranty, express or implied, or assumes any legal liability or responsibility for the accuracy, completeness, or usefulness of the contents of this report. Reference herein to any specific commercial product, process or service by trade name, trademark, manufacturer, or otherwise does not necessarily constitute or imply endorsement, recommendation or favoring by the United States Government or any agency thereof.
\end{abstract}

(C) 2020, Denise Hoffman, Jonah Deutsch, and Britta Seifert. All rights reserved. Short sections of text, not to exceed two paragraphs, may be quoted without explicit permission provided that full credit, including (C) notice, is given to the source. 


\begin{abstract}
About the Center for Retirement Research
The Center for Retirement Research at Boston College, part of a consortium that includes parallel centers at the National Bureau of Economic Research, the University of Michigan, and the University of Wisconsin-Madison, was established in 1998 through a grant from the U.S. Social Security Administration. The Center's mission is to produce first-class research and forge a strong link between the academic community and decision-makers in the public and private sectors around an issue of critical importance to the nation's future. To achieve this mission, the Center conducts a wide variety of research projects, transmits new findings to a broad audience, trains new scholars, and broadens access to valuable data sources.
\end{abstract}

Center for Retirement Research at Boston College

Hovey House

140 Commonwealth Ave

Chestnut Hill, MA 02467

Tel: 617-552-1762 Fax: 617-552-0191

https://crr.bc.edu

Affiliated Institutions:

The Brookings Institution

Mathematica - Center for Studying Disability Policy

Syracuse University

Urban Institute 


\begin{abstract}
This study uses insights from the behavioral economics literature to provide a comprehensive diagnosis of seven SSA written communications that include information on earnings reporting. We conducted a behavioral assessment of the documents' contents on earnings reporting to identify bottlenecks that may prevent beneficiaries from taking desired actions in four key domains: notice and open the document, locate and read the material on earnings reporting, decide to act, and act. The findings from this exercise are only suggestive and the extent to which modifying any of the components reviewed would affect earnings reporting is unknown.
\end{abstract}

The paper found that:

- Only one of the reviewed documents is sent at a time when the reporting requirement is likely to be actionable.

- Although the documents are generally formatted so that readers can locate material on earnings reporting, much of the text is dense and key content could be missed.

- The guidance on earnings reporting varies in clarity and salience; no document includes a concrete reporting deadline that would help beneficiaries avoid overpayments.

- Three of the seven documents provide comprehensive, accessible, and actionable information to facilitate earnings reporting.

- None of the seven documents reviewed contain communication strategies that are likely to be effective in all four categories.

The policy implications of the findings are:

- In our assessment, potential shortcomings in SSA communications on earnings reporting may contribute to beneficiary lack of awareness about reporting, which other research has linked to overpayments.

- We provide sample reporting reminders, designed based on behavioral economics insights, as a potential starting point for SSA to consider and test earnings reporting reminders. 


\section{Introduction}

Social Security Disability Insurance (SSDI) is a safety net program administered by the Social Security Administration (SSA) for workers with disabilities and their dependents. As much as this program can be an essential lifeline for beneficiaries, overpayment of benefits can create challenges for beneficiaries and SSA alike. Overpayments occur when SSA issues a benefit to which a beneficiary is not entitled and, in most cases, beneficiaries are required to repay the overpayment debt to SSA.

Overpayments can occur for many reasons, but work-related overpayments account for the largest portion of all SSDI overpayment dollars (SSA 2019). The median work-related overpayment amount is over $\$ 9,000$, which can be large relative to beneficiary income (Hoffman et al. 2019) and qualitative evidence suggests that they can be distressing for beneficiaries (Gubits et al. 2013; O’Day et al. 2016; Hoffman et al. 2017; Kregel 2018). Furthermore, workrelated overpayments amount to an average of nearly $\$ 800$ million per year over a five-year period (SSA 2019); they are not always recovered; and there is an administrative cost for overpayments that are recovered (SSA Office of the Inspector General [OIG] 2015, SSA 2018).

Beneficiaries are at risk of work-related overpayments when they engage in substantial gainful activity after exhausting SSDI work incentives that allow them to test work. Although initial and ongoing eligibility requires individuals to be unable to engage in substantial gainful activity because of a physical or mental impairment, some beneficiaries pursue substantial gainful activity after award. In 2020, substantial gainful activity is measured as monthly earnings over $\$ 1,220$ for non-blind beneficiaries; this threshold is indexed and changes in most years. SSDI beneficiaries can test their ability to work for 12 months - not necessarily consecutive-without any effect on their benefits, but after that point beneficiaries are not entitled to benefits in months in which they engage in substantial gainful activity. If SSA pays benefits for such months, beneficiaries will experience work-related overpayments. Recent estimates suggest that 71 percent of beneficiaries at risk for a work-related overpayment were overpaid in a three-year period. 
Work-related overpayments most often occur because SSA does not have access to the earnings information needed to suspended benefits in real time. ${ }^{1}$ Beneficiaries are required to report their earnings to SSA promptly, but often neglect their reporting responsibility. Indeed, 83 percent of SSDI beneficiaries with work-related overpayments were overpaid because they failed to report earnings to SSA timely (SSA OIG 2018). Qualitative evidence suggests that many overpaid beneficiaries are unaware of the earnings reporting requirements (Kregel 2018). Similarly, a Government Accountability Office (GAO) report noted that SSA work reporting requirements are unclear and beneficiaries may "receive inadequate and inconsistent guidance" on earnings reporting (GAO 2015). For example, the timeframe in which beneficiaries are required to report earnings is not concretely defined.

In this article, we review the written communications that SSA uses to remind beneficiaries to report their earnings, drawing on lessons from the behavioral economics literature. SSA has a strategic goal to minimize work-related overpayments. This study provides actionable information for one potential approach to help make progress towards that goal.

\section{Overview of Behavioral Economics Literature on Compliance}

Standard microeconomics assumes that actors have boundless cognitive ability and rationality. That is, they can calculate costs and benefits of decisions without bias, make choices based on optimizing expected net benefits, and act on those choices. Behavioral economics, on the other hand, attempts to account for and explain the limits of human cognition and rationality by drawing on empirical research in psychology and other fields (see Kahneman 2011 and Thaler and Sunstein 2009 for reviews). A growing field of research evaluates interventions based on insights from behavioral economics (sometimes referred to as behavioral interventions) to improve the functioning of public programs (see Madrian 2014 for a review).

SSDI's earnings reporting requirement fits within the broader category of compliance, and the most studied application of behavioral interventions to increase compliance involves taxes. In these studies, compliance can include reporting (as is the focus of our analysis) or

\footnotetext{
${ }^{1}$ Work-related overpayments can occur even when beneficiaries report their earnings to SSA timely. This is because SSA may attempt to gather other evidence of earnings and then must take additional steps to process earnings information including verifying when the work occurred, documenting the use of work incentives, and determining for which months benefits should be suspended or terminated for work. Overpayments can accrue while processing is underway. Given this constraint, timely reporting would not entirely eliminate overpayments, but could reduce the size of overpayments.
} 
payment of owed funds. Hallsworth (2014) reviews experimental interventions to increase tax compliance, dividing the studies into categories based on their emphasis on deterrence or nondeterrence messaging. Deterrence approaches highlight the probability of audit and consequences of action or inaction, key parameters in the neo-classical theory of tax compliance introduced by Allingham and Sandmo (1972) and more general theory of compliance introduced by Becker (1968). Non-deterrence alternatives emphasize moral suasion, provision of public goods (Rabin 1993), social norms (Cialdini et al. 1991) and other features from behavioral economics.

Overall, there is mixed evidence about whether these strategies improve tax compliance in practice. Hallsworth (2014) finds that most deterrence approaches increase reported tax income. Most notably, Slemrod et al. (2001) found impacts as large as 12 percent from being notified about the increased probability of audit for some groups. Kleven et al. (2011) also found large impacts by increasing the perceived chance of an audit. Chirico et al. (2019) found that letters emphasizing deterrence had larger impacts than those that used non-deterrence approaches (in a single, multi-armed experiment).

The impacts of non-deterrence approaches have been mixed. Hallsworth (2014) finds that roughly half of the non-deterrence interventions found positive impacts (where the targets of the studies were a mix of individual tax-payers and firms). The Behavioural Insights Team of the Cabinet Office in the United Kingdom conducted eight behavioral interventions targeting tax compliance using insights to promote social norms and deter procrastination, along with other behavioral strategies (Cabinet Office 2012). In general, they found positive impacts of these modified messages on compliance behaviors when compared with standard messages. Hallsworth et al. (2017), Kettle et al. (2016), and Larkin et al. (2019) found that messaging involving social norms increases tax payments. However, Blumenthal et al. (2001), Torgler (2012), and John and Blume (2018) found that social norm messaging was ineffective or detrimental. $^{2}$

Other studies examine the impacts of behavioral interventions on compliance with other regulations. Richburg-Hayes et al. (2017) found that behaviorally-informed messages to

\footnotetext{
${ }^{2}$ A related literature focuses on behavioral interventions to increase tax-paying by firms (e.g., Iyer et al. 2010, Ariel 2012, Boning et al. 2019, Ortega and Sanguinetti 2013). There is also a literature on behavioral interventions to increase take up of social benefits (e.g. Bhargava and Manoli 2011, Dynarski and Scott-Clayton 2006). Both of these sub-fields are less relevant to the topic of SSDI earnings reporting and so are not reviewed here.
} 
noncustodial parents about child support payments increased the proportion of parents that submitted payments, but not the average amount of payments. In a similar study focused on the same topic, Baird et al. (2016) found a mix of positive and null impacts. And Darling et al. (2017) found positive impacts of a behaviorally-informed email to Unemployment Insurance recipients to encourage them to attend a required meeting.

Simply reminding people of tasks has shown to be effective, due to limited attention (Bertrand et al. 2004) and the tendency to procrastinate and forget (Laibson 1997). Multiple studies found that additional reminders increase the rate of desired actions, such as filing and paying taxes (Chirico et al. 2019, Gillitzer and Sinning 2018, Guyton et al. 2016, Kettle et al. 2016), making child support payments (Baird et al. 2016), charitable giving (Damgaard and Gravert 2018), reengaging in a welfare-to-work program (Farrell et al. 2016), reaching a personal savings goal (Karlan et al. 2016), and getting vaccinations (Busso et al. 2015, Milkman et al. 2011). This may be particularly relevant to SSDI earnings reporting if beneficiaries have many competing demands for time and attention, such as management of complex healthcare needs, that crowd out attention on the desired compliance actions (Bertrand et al. 2004).

The broader behavioral economics literature has identified specific behavioral strategies applied to communications, including reducing the complexity of the message, heightening salience, clarifying and providing guidance on action steps, conveying that the relevant action is easy to complete, providing planning prompts, and using a positive, personal tone. We elaborate on these features and how they relate to SSA communications on earnings reporting in Section $\mathrm{V}$.

Finally, the SSA disability programs have tested communications designed based on insights from behavioral interventions. In one study, the Office of Evaluation Sciences and SSA collaborated to send letters to Supplemental Security Income (SSI; a means-tested income support program) recipients to remind them to report earnings (Zhang et al. 2019). There were four versions of the reminder letter, which incorporated social norms messaging, deterrence messaging, both, or neither. The study, which included 50,000 beneficiaries, found that receiving any one of four reminder letters led to an increased rate of earnings reporting, though this effect decayed over time. The study did not find any differences in reporting rates across the four reminder letters. SSA and the Office of Evaluation Sciences also tested a behavioral intervention that provided outreach to denied SSDI applicants to inform them about employment 
services. However, there was no evidence that the outreach achieved the intended goal of decreasing application appeals.

In a separate study, Hock et al. (2019) tested different reminder strategies to encourage SSDI beneficiaries to enroll in the Promoting Opportunity Demonstration (POD), an initiative to test the effectiveness of an alternative benefit offset rule. The study found that preliminary notification postcards-sent before the primary letter soliciting enrollment in the demonstration, reminder postcards, and reminder phone calls were all effective in increasing enrollment in the demonstration.

\section{Methods}

The first step in our analysis was to identify written SSA communications that include information about SSDI earnings reporting. We began by compiling a list of known SSA communications that mention earnings reporting requirements including SSA forms, letters, publications, fact sheets, websites, blog posts, archived webinars, and social media posts. We shared our list with SSA, and asked them to 1) identify the documents believed to be most widely seen by working SSDI beneficiaries, 2) share any omitted communications, and 3) provide information on the timing and frequency with which these materials are shared or made available, and the mode of dissemination (that is, delivered by mail, presented at application, searchable on the SSA website, available upon request, or obtained by other means). ${ }^{3}$

After incorporating feedback from SSA, we developed a final list of seven key communications. Although notifying or reminding beneficiaries to report earnings is not the primary objective of any of these communications, they each offer an opportunity to do so. Table 1 shows the final list of the communications we include in our behavioral audit. ${ }^{4}$ Beneficiaries may also be informed about earnings reporting requirements from other sources that we did not analyze, including written or verbal reminders from organizations that provide employment services (e.g. state vocational rehabilitation agencies, Ticket to Work providers) and benefit counseling (Work Incentives Planning and Assistance providers).

\footnotetext{
${ }^{3}$ The following SSA offices provided feedback on our list: Office of Communications, Office of Research Demonstrations and Employment Support (ORDES), Office of Income Security Programs (OISP), and Office of Disability Policy (ODP)/Office of Vocational Education and Policy Process (OVEPP).

${ }^{4}$ SSA communications that we did not include in our review primarily include webpages, blogposts, and webinars.
} 


\section{Table 1. Primary SSA Communications that Discuss Earnings Reporting}

\begin{tabular}{|c|c|c|c|}
\hline Communication & Description & Mode of distribution & $\begin{array}{l}\text { Frequency and } \\
\text { timing of } \\
\text { distribution }\end{array}$ \\
\hline $\begin{array}{l}\text { SSDI application } \\
\text { form }\end{array}$ & $\begin{array}{l}\text { 7-page application form; the last } \\
\text { page contains information about } \\
\text { earnings reporting requirements. }\end{array}$ & $\begin{array}{l}\text { Available in person or online. } \\
\text { Application can also be } \\
\text { completed by phone. }\end{array}$ & Once; at application \\
\hline $\begin{array}{l}\text { Reporting } \\
\text { Responsibilities for } \\
\text { Disability Insurance } \\
\text { Benefits }\end{array}$ & $\begin{array}{l}\text { 2-page document that includes a } \\
\text { bulleted list of all reporting } \\
\text { responsibilities and instructions on } \\
\text { first page }\end{array}$ & $\begin{array}{l}\text { Upon receipt of signed } \\
\text { application, handed to applicants } \\
\text { who interview in person or } \\
\text { mailed to applicants who } \\
\text { interview on the phone. If } \\
\text { applied online, mailed upon } \\
\text { award. }\end{array}$ & $\begin{array}{c}\text { Once; at application } \\
\text { or award }\end{array}$ \\
\hline Award letter & $\begin{array}{l}\text { 4-page letter that includes benefit } \\
\text { amount and additional } \\
\text { information; reporting information } \\
\text { on second page. }\end{array}$ & $\begin{array}{l}\text { Mailed to beneficiaries upon } \\
\text { decision of an award. }\end{array}$ & Once; at award \\
\hline $\begin{array}{l}\text { What You Need to } \\
\text { Know When You Get } \\
\text { Social Security } \\
\text { Disability Benefits }\end{array}$ & $\begin{array}{l}28 \text {-page publication that includes } \\
\text { various topics; reporting } \\
\text { requirements on page } 8 \text {, referred to } \\
\text { in table of contents. }\end{array}$ & $\begin{array}{l}\text { Mailed to all beneficiaries upon } \\
\text { decision of an award; enclosed } \\
\text { with award letter; and available } \\
\text { online. }\end{array}$ & Once; at award \\
\hline $\begin{array}{l}\text { Annual cost of living } \\
\text { adjustment (COLA) } \\
\text { letter }\end{array}$ & $\begin{array}{l}\text { Roughly 3-page letter that notifies } \\
\text { beneficiaries of any increases in } \\
\text { benefit amount; reporting } \\
\text { requirements on second page. }\end{array}$ & $\begin{array}{l}\text { Mailed annually to all } \\
\text { beneficiaries toward the end of } \\
\text { each calendar year. }\end{array}$ & Annually \\
\hline $\begin{array}{l}\text { Working While } \\
\text { Disabled }\end{array}$ & $\begin{array}{l}\text { 23-page SSA publication; includes } \\
\text { work-related information for both } \\
\text { SSDI and SSI beneficiaries; SSDI } \\
\text { reporting content on page } 5 \text { and } \\
\text { referred to in table of contents. }\end{array}$ & $\begin{array}{l}\text { If beneficiaries express interest in } \\
\text { working, paper copy may be } \\
\text { mailed or link to online } \\
\text { document shared. }\end{array}$ & $\begin{array}{l}\text { Available with } \\
\text { beneficiary action }\end{array}$ \\
\hline $\begin{array}{l}\text { Red Book: A } \\
\text { Summary Guide to } \\
\text { Employment Supports } \\
\text { Under the SSDI and } \\
\text { SSI Programs }\end{array}$ & $\begin{array}{l}\text { 60-page SSA publication focused } \\
\text { on employment; reporting } \\
\text { requirements on page } 9 \text { and } \\
\text { referred to in table of contents. }\end{array}$ & $\begin{array}{l}\text { Posted online and updated } \\
\text { annually. Not distributed directly } \\
\text { to beneficiaries; they may be } \\
\text { referred to it or find it by } \\
\text { searching online. May also be } \\
\text { distributed by third-party service } \\
\text { providers. }\end{array}$ & $\begin{array}{c}\text { Available with } \\
\text { beneficiary action or } \\
\text { upon referral }\end{array}$ \\
\hline
\end{tabular}

We conducted a behavioral audit of the key materials: a structured review to identify potential bottlenecks that may prevent beneficiaries from taking desired actions. The potential bottlenecks and presumed strengths are grounded in the behavioral economics literature around compliance and have not been directly tested in the context of earnings reporting for SSDI beneficiaries. To conduct the audit, we developed a template structured around the four key 
steps that beneficiaries would have to take if the communication were to lead to compliance actions:

1. Notice and open document: Under what conditions does a beneficiary encounter the document? Is the document title and opening compelling?

2. Locate and read the material on earnings reporting: Is information on earnings reporting easy to find? Does the document use headings, bullets, formatting, and language to facilitate the reader's ability to digest the key information?

3. Decide to act: Does the text provide clear, salient deadlines for reporting, and create a sense of urgency? Does text motivate reporting by emphasizing consequences for not reporting or invoking social norms or reciprocity to promote reporting?

4. Act: Does the text provide clear action steps, and necessary information such as phone numbers or web addresses for reporting? Is all key information about earnings reporting presented in the same section of the document?

Using the template, we reviewed the seven communications across the four domains, considering factors such as document structure, formatting, phrasing, and information provided. We created annotated exhibits to highlight each communication's potential strengths and weaknesses. Finally, we synthesized findings across all seven communications on earnings reporting and developed two sample earnings reporting reminders (a letter and a postcard) that draw on behavioral insights and address weaknesses identified in the behavioral audit of existing communications. In the next section, we present findings from our assessment of the first domain, noticing and opening a document.

\section{Potential Barriers to Noticing and Opening SSA Communications with Earnings Reporting Information}

The literature suggests that both the mode that SSA uses to disseminate a document and the document's perceived importance to the beneficiary will affect the likelihood that a beneficiary will open a document and notice content on earnings reporting. Behavioral economics discusses the concept of salience: the extent to which some pieces of information are more immediately relevant and noticeable than others. Communications that include specific 
information about the receipt of benefits are likely to be more salient than documents that list various program rules.

The literature also suggests that the timing of communications affects their salience. Communications about earnings reporting may be less salient to beneficiaries when they are applying for benefits because the reporting requirement itself is not yet in effect. Similarly, if beneficiaries are not working or planning work at the time of award, the salience of information about earnings reporting may be low at award, even if award materials provide information about benefits. Exhibit 1 depicts the dissemination mode for the seven key documents with information on earnings reporting. We review the timing and how it might relate to the salience of each document below.

\section{Exhibit 1. Dissemination of SSA Communications with Earnings Reporting Information}

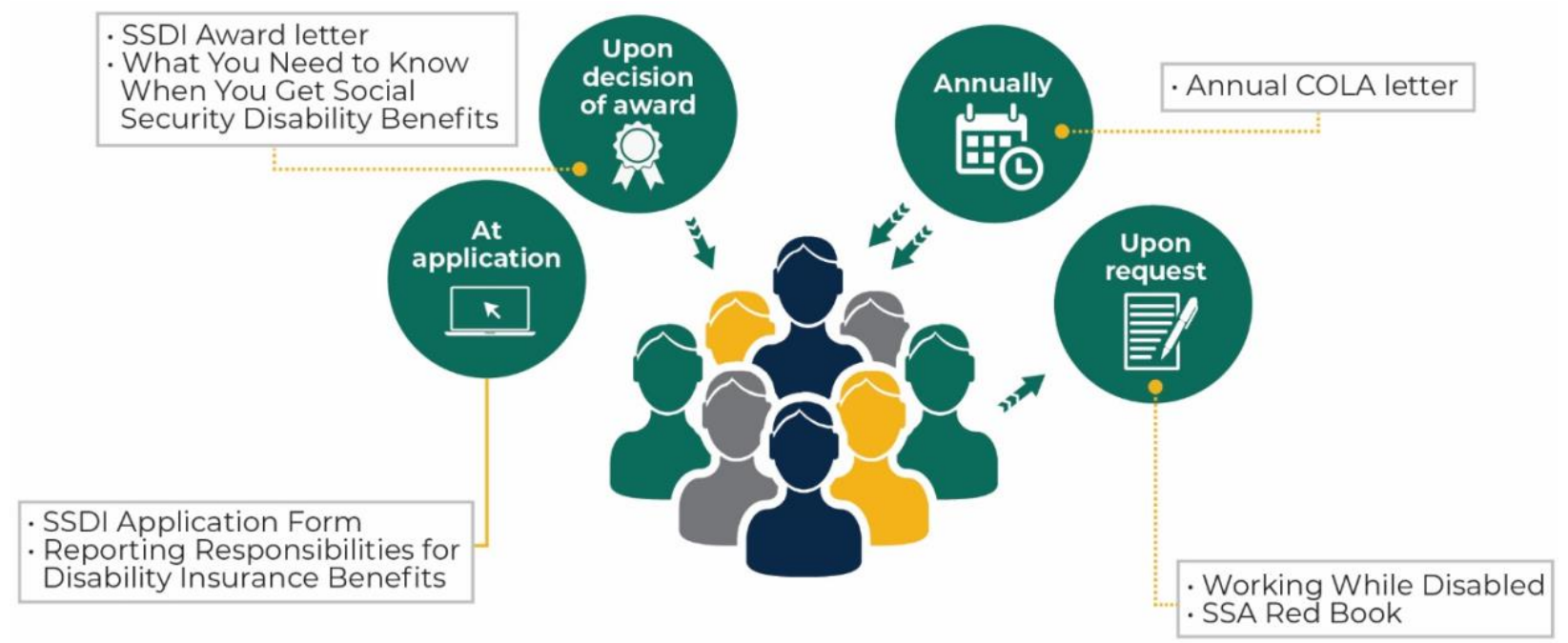

Application materials: All SSDI beneficiaries (or a representative assisting beneficiaries) access the application form, making this a universal point of contact. Those who apply in person in an SSA field office or by phone also receive Reporting Responsibilities for Disability Insurance Benefits at the time of application. Thus, we would expect a substantial portion of beneficiaries to encounter one or both communications at application.

However, the requirement to report earnings is not actionable for SSDI awardees at the time of application because only individuals with earnings below the substantial gainful activity 
threshold meet the initial eligibility criteria for SSDI. Furthermore, given the uncertain outcome at the time of application, applicants may not be motivated to read the final two pages of the application form that begins with "For Your Information" or open the Reporting Responsibilities for Disability Insurance Benefits pamphlet. Additionally, there is a notable amount of time between application (which often includes appeals) and award. Beneficiaries who are awarded benefits upon application wait an average of over 100 days between application and decision, those awarded after one appeal wait an average of more than 200 days, and those who submit an additional appeal may wait an additional 400-600 days (SSA 2019). Hence, beneficiaries may not recall information on reporting earnings when the reporting requirements become relevant to them.

Award materials. Beneficiaries are likely to open the award letter because it is sent directly to them and contains information that affects their financial well-being. It is unclear how likely beneficiaries are to read the enclosed document, What You Need to Know When You Get Social Security Disability Benefits. While these two communications are nearly universally received, content about earnings reporting requirements may not be salient to beneficiaries at the time of award. Program rules allow beneficiaries to earn an unlimited amount without affecting their benefits for 12 months, so they cannot be overpaid in their first year of award. Indeed, 75 percent of beneficiaries who are overpaid receive benefits for three or more years before overpayments begin to accrue (Hoffman et al. 2019). Information about earnings reporting contained in award materials, therefore, may not reach beneficiaries at a time when it is likely to be relevant or actionable. Therefore, the communications are relying on the ability of beneficiaries to remember the earnings reporting requirement and report earnings later in their benefit spell.

Annual COLA notice. SSA also directly sends beneficiaries an annual cost of living adjustment (COLA) notice, which beneficiaries are likely to open because it contains information about their benefit amounts. After award, the COLA notice is the only communication that beneficiaries receive regularly (once per year) that includes content about the requirement to report earnings. Therefore, this communication is more likely than application or award materials to arrive at a time when beneficiaries are working or considering working. As a result, information about earnings reporting, may be more salient to beneficiaries in this communication. 
Available with beneficiary action. The SSA publications Working While Disabled and the Red Book are not disseminated directly to beneficiaries unless a beneficiary has taken action. A beneficiary would typically only obtain these communications if they express interest in working to an SSA representative or other service provider, search for information online, or follow the reference in What You Need to Know When You Get Social Security Disability Benefits. Therefore, while information about earnings reporting presented in these materials may be salient to beneficiaries, it is unlikely that most beneficiaries are aware of these materials.

Beneficiaries are most likely to read the SSDI application, SSDI award letter, and COLA letter; but only the COLA letter comes at a time when the reporting requirement is likely to be actionable. SSA currently only reminds beneficiaries about reporting requirements in text that is contained within the annual COLA notice and does not use any communications that solely address earnings reporting. The literature demonstrates that reminders are an effective tool, and the Government Accountability Office (2015) recommended that SSA explore ways to increase the frequency of reporting reminders sent to SSDI beneficiaries.

\section{Diagnosing Potential Bottlenecks in Reading, Deciding to Act, and Acting on Earnings Reporting Requirements}

For the communications that include information on earnings reporting to be effective, they need to convince beneficiaries who have opened the documents to (a) locate and read the material on earnings reporting, (b) decide to act, and (c) act. This section summarizes the structure, design, and content of these communications and assesses their ability to promote these desired actions. Table 2 summarizes the behavioral features identified in the literature that are relevant to SSA communications on earnings reporting. Exhibits 2-7 display the relevant sections from the communications, with annotations highlighting features that are likely to be strengths and weaknesses based on the insights from the literature illustrated in Table $2 .{ }^{5}$

\footnotetext{
${ }^{5}$ We do not display "Reporting Responsibilities for Disability Insurance Benefits" because it is nearly identical to the excerpt from the application form (Exhibit 1).
} 
Table 2. Key Behavioral Insights Identified in the Literature and Relevant to SSA

Communications

Feature

Insight from behavioral science literature

Locate and read content on earnings reporting

Clear, concise headings and sub- Because people have limited attention, they use conscious headings to draw attention to important content and subconscious heuristics to decide which stimuli to notice (Kahneman 2011). People have a tendency to focus on headings, boxes, and images, often ignoring detailed text (Behavioural Insights Team 2012).

Use of bullets and other Use of bullets, blank space, and other formatting can reduce formatting to indicate events that must be reported, options for reporting, and/or information needed when reporting

\section{Decide to act}

Clear description of reporting Making the requested action salient and the content less requirement and the work-related events that require reporting complex can encourage the desired response (Bettinger et al. 2009).

Use of a positive, congratulatory tone about returning to work

People are more likely to digest information if it is presented as good news rather than bad news (Karlsson et al. 2009)

Emphasis on potential People react more strongly to potential losses than potential consequences of needing to repay gains (Tversky and Kahneman 1991), and communications SSA due to overpayment can influence behavior by emphasizing potential losses (Chojnacki et al. 2017; Darling et al. 2017)

\section{Act}

Making it easy to find phone numbers, web sites, etc.

Use of deadlines to avoid procrastination Emphasis on reporting being easy and fast.

Reducing the steps the reader must take can increase responsiveness (Glosser et al. 2016, Bertrand et al. 2004)

Deadlines can overcome the tendency to procrastinate (Ariely and Wertenbroch 2002; Dechausay et al. 2015)

If requested action seems onerous, people are more likely to procrastinate (Laibson 1997, Frederick et al. 2002) 
Exhibit 2. SSDI Application Form Excerpt

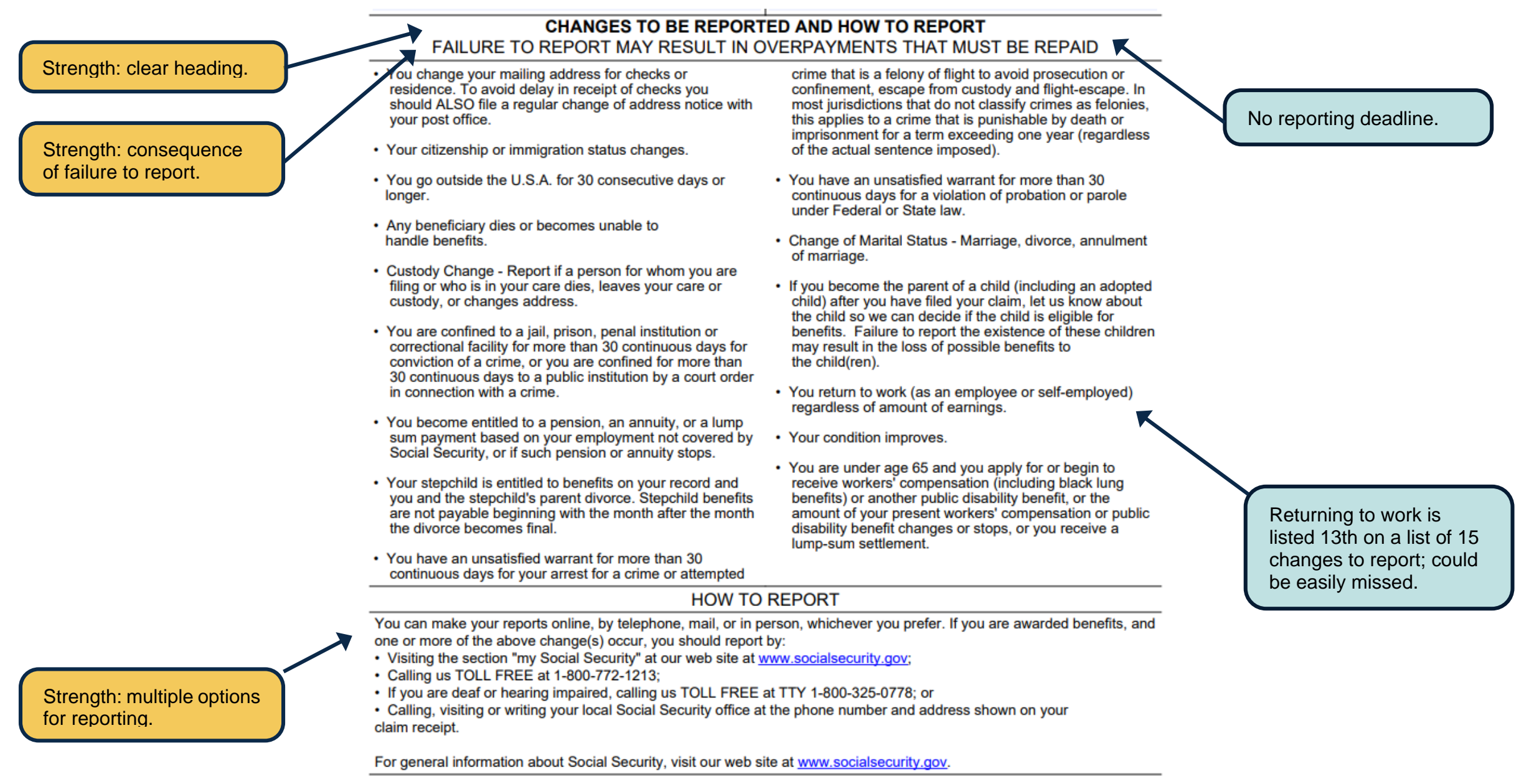




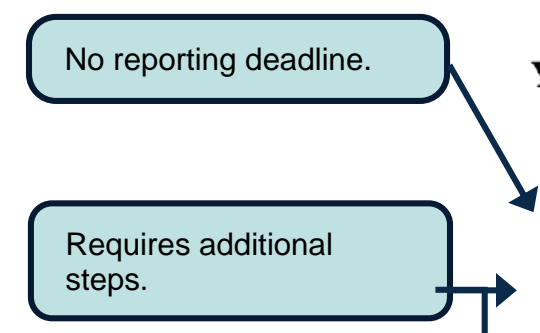

\section{Your Responsibilities}

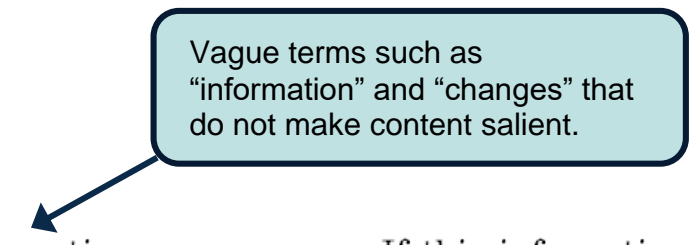

We based our decision on information you gave us. If this information

changes, it could affect your benefits. For this reason, it is important that

you report changes to us right away.

No consequence of

We have enclosed a pamphlet, "What You Need To Know When You Get

failure to report.

Social Security Disability Benefits." It tells you what you must report and

how to report. Please be sure to read the parts of the pamphlet that tell you

what to do if you go to work or your health improves.

A vocational rehabilitation or employment services provider may contact you to help you in going to work. The provider may be from a State agency or work under contract with Social Security.

Content not about

responsibilities and not

related to other content

If you go to work, we have special rules that let us continue your cash payments and health care coverage. To learn more about how work and earnings affect disability benefits, visit our website at

Single option for
reporting; embedded in text. www.socialsecurity.gov/work/. You may also call or visit any Social Security office to ask for the following publications:

- Social Security - Working While Disabled...How We Can Help (SSA Publication No. 05-10095).

- Social Security - If You Are Blind--How We Can Help (SSA Publication No. 05-10052). in section.

Text on continued benefits could lead to misunderstanding. 
Exhibit 4. What You Need to Know When You Get SSDI Benefits (Included with Award Letter Package) Excerpt

What you must report to us

Strength: clear heading.

Please notify us promptly by phone, mail, or in person whenever a change occurs that could affect your benefits We explain the changes you must report to us on pages 9-15.

Family members receiving benefits based on your work also should report events that might affect their payments.

Information you give to another government agency may be provided to Social Security by the other agency, but you also must report the change directly to us.

NOTE: If we find that you gave us false information on purpose, your benefits will be stopped. For the first violation, your benefits will be stopped for six months; for the second violation, 12 months; and for the third, 24 months. Also, if you don't report a change, it may result in your being paid too much. If you're overpaid, you'll have to repay the money.

No reporting deadline

Reporting options not provided within section.

Have your claim number handy when you report a change. If you receive benefits based on your own work, your claim number is the same as your Social Security number followed by the letters "HA." If you receive benefits on someone else's work, your claim number will be the other person's Social Security number followed by a different letter. The award notice you received when your benefits started shows your claim number. You also

Does not describe which changes affect benefits; unclear that earnings reporting is required.

8

should be prepared to give the date of the change, and, if different, the name of the person about whom the report is made.

\section{If you work while receiving disability payments}

Strength: clear heading

You should tell us if you take a job or become self-employed, no matter how little you earn. Please let us know how many hours you expect to work, and when your work starts or stops. If you still have a qualifying disability, you'll be eligible for a trial work period, and you can continue receiving benefits for up to nine months. Also, tell us if you have any special work expenses because of your disability (such as specialized equipment, a wheelchair or even prescription drugs), or if there's any change in the amount of those expenses.

Consequence of failure to report is not near text on earning reporting requirements.
Strength: information needed when reporting
Strength: events that necessitate reporting and what information to report.

Reporting conditions embedded in text rather than bulleted list 


\section{IMPORTANT INFORMATION}

Strength: clear heading

First paragraph is only about Ticket to Work;

some may stop reading.

\section{What If I Work Or Want To Return To Work?}

Ticket to Work is a voluntary program that helps people getting disability benefits go to work.

Employment networks or your State vocational rehabilitation agency can help you find, prepare

for, and keep a job. If you join this program, there is no cost to you. We may also set aside review of your medical condition. You can find a list of service providers, benefits and work incentives counselors, and get your questions answered by contacting the Ticket to Work Help Line at 1-866-968-7842 (TTY 1-866-833-2967). You also can visit https://choosework.ssa.gov/findhelp/online.

No reporting deadline.

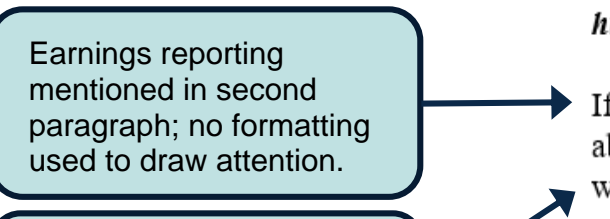

If you work, you must call us right away at 1-800-772-1213 (TTY 1-800-325-0778) to tell us about any earnings you have. There are special rules that help people with disabilities return to work without losing their benefits and Medicare or Medicaid. You must follow these rules and

Text on continued benefits could lead to misunderstanding.

Strength: consequence of failure to report report your earnings to help prevent any overpayment that you may have to repay. To learn more, please see our free pamphlets, Working While Disabled - How We Can Help (No. 0510095) or The Red Book (No. 64-030), our guide to employment support programs. You can find them at www.socialsecurity.gov/pubs and www.socialsecurity.gov/redbook online.

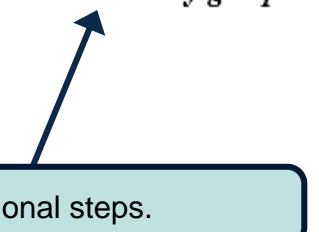

Strength: Phone numbers in bold.

Single option for reporting.

Requires additional steps. 


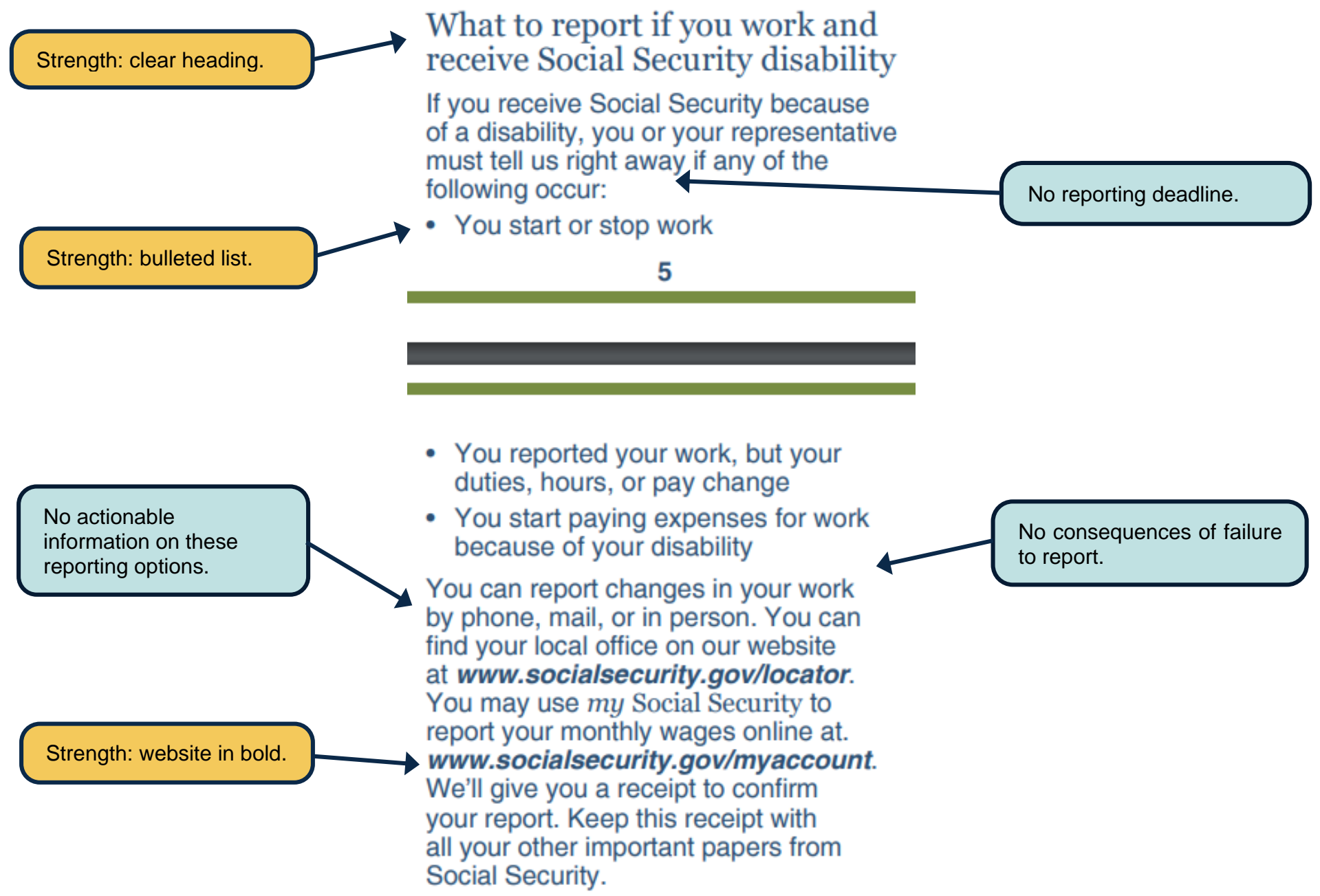




\section{Exhibit 7. Red Book: A Summary Guide to Employment Supports for Persons with Disabilities Under the SSDI and SSI Programs}

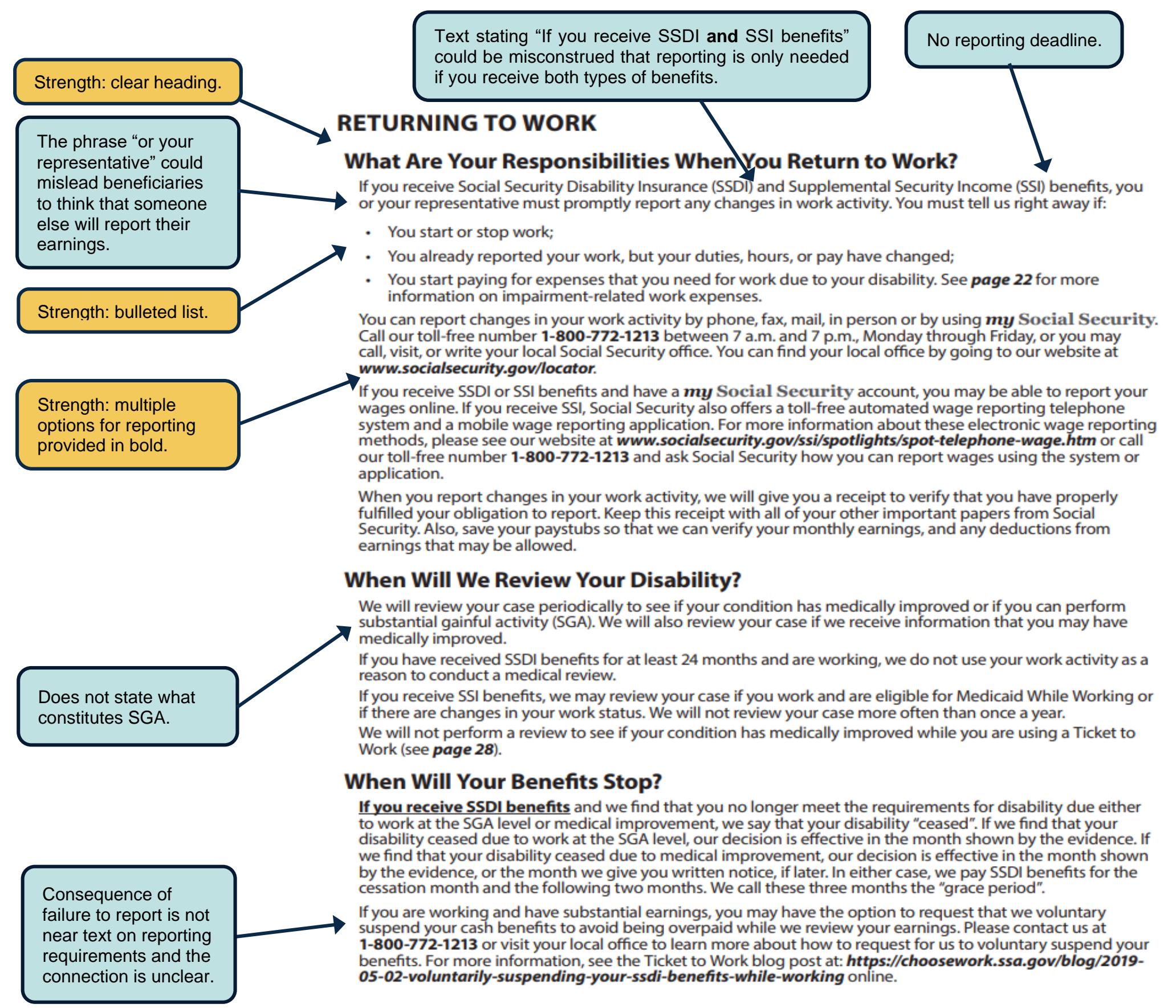


Locating content on earnings reporting. Overall, the documents are organized so that attentive readers can likely find content on earnings reporting. Shorter documents include material on earnings reporting within the first two pages: page one of the two-page Reporting Responsibilities for Disability Insurance Benefits pamphlet, page two of the four-page award letter, and on the top of the second page of the three-page COLA letter. Documents longer than four pages have a table of contents that direct readers to the relevant content, which is on page nine of the 60-page Red Book, page five of the 23-page Working While Disabled, and page nine of the 28-page What You Need to Know When You Get Social Security Disability Benefits. The one exception is the SSDI application form, which does not have a table of contents and includes information on reporting requirements on the last page of the seven-page form.

Some of the communications use clear headings to draw attention to sections that include information on earnings reporting requirements. The COLA notice, Working While Disabled: How We Can Help, and Red Book have sections devoted to work or earnings reporting. For example, the Red Book has a section called "What Are Your Responsibilities When You Return to Work?" However, in the COLA notice, the material on earnings reporting is embedded in dense text in the section on work and may be missed. One communication, What You Need to Know When You Get Social Security Disability Benefits, has a section called "What you must report to us" with a subsection "If you work while receiving disability payments," however, the subsection is not in the table of contents and could be missed. The remaining three documents group this information alongside other reporting requirements, and it is possible that the earnings reporting requirement could be overlooked.

The documents generally display limited use of bullets, blank space, and bolding to highlight key information and reduce cognitive burden of the reader (Johnson et al. 2012). For example, the information on earnings reporting in the COLA notice is in a dense paragraph that follows another dense paragraph about resources to help with return to work. Beneficiaries who are already working may not advance to the second paragraph about reporting. Two exceptions that use formatting well are Working While Disabled: How We Can Help and the Red Book, which both have a bulleted list of three situations in which beneficiaries should report to SSA.

Deciding to act. Some of the documents, such as the Red Book and Working While Disabled, use fairly clear language to explain the reporting requirement. Other communications, such as the award letter and COLA notice, conflate earnings reporting with the rules that govern 
benefit entitlements when beneficiaries work and with programs aimed at helping beneficiaries obtain employment. The award letter refers only to vague changes that must be reported, and the application form lists earnings in a long list of reportable events.

Some communications, such as the COLA notice, mention the possible consequence of needing to repay overpayments when describing the reporting requirements to (a) make the issue salient, and (b) invoke loss-aversion. Other documents, such as What You Need to Know When You Get Social Security Disability Benefits, mention overpayments in the document, but outside of the section focused on earnings reporting. That material may not be read by working beneficiaries and, if read, the connection between overpayments and failure to report work may be unclear.

The direct communications (award letter and COLA notice) do not congratulate working beneficiaries for finding employment. Rather, they generally start by discussing the additional requirements that these beneficiaries face. Karlsson et al. (2009) find that information is more likely to be digested if it is contained in a communication that leads with good news, rather than bad news.

Acting. The documents we reviewed generally provide only partial information on how to report earnings and the information is not well formatted. The award letter does not provide a phone number for beneficiaries to call to report earnings, and instructs readers to obtain additional documents. Other communications (What You Need to Know When You Get Social Security Disability Benefits; Working While Disabled) place the phone number and other contact information in another section, and do not refer the reader to that section directly. The other communications generally list the phone number and website for reporting, but none of them present reporting options as a bulleted list to make the information easy to find quickly.

The documents generally do not draw on other tools for motivating behavior, such as establishing urgency through deadlines. Most of the documents indicate that earnings should be reported "right away" or "promptly," which are not specific and are subject to interpretation. The only documents that include a reporting deadline are the SSDI application and Reporting Responsibilities for Disability Insurance Beneficiaries, which indicate that earnings should be reported within 3 months and 15 days after the end of the year. However, this timeframe is insufficient to avoid overpayments. In addition, none of the communications emphasize to the 
reader that reporting can be completed in a short amount of time, another strategy to avoid procrastination.

\section{Example Reminder Letter and Postcard}

Drawing on behavioral insights and our audit of existing SSA materials, we developed sample communications that SSA could consider for use as additional earnings reporting reminders for SSDI beneficiaries. We developed two behaviorally-informed reporting reminders, presented in Exhibits 8 and 9, respectively: a letter and a postcard. The key features of these reminders include:

- A simple heading in bolded, red text to alert readers to the topic.

- An upbeat opening message about employment.

- A message about the consequences of unreported earnings (negative reinforcement).

- A clear call to action that emphasizes ease/quickness of reporting, presents multiple ways to report, and provides necessary information such as phone numbers.

- Use of bulleting, icons, and brief bolded text to make the action salient and memorable.

- A resource for questions, including options for non-English speakers.

If SSA chooses to develop earnings reporting reminders, other considerations include the target population, timing, and content of these communications. For example, would reminders be sent to all beneficiaries, or to a targeted group of beneficiaries identified as higher risk for overpayment? What frequency and timing are most effective? Also, a review of reminder materials by a cognitive linguistics expert may provide additional insight into how beneficiaries process the information provided in reporting reminders, and could be used to refine content.

Finally, a best practice is to rigorously test the sample materials before disseminating them to beneficiaries at a large scale. In this testing phase, several versions of the communications could be tested to identify the most effective timing, features, or version. Then a final communication, or set of communications, could be developed and disseminated to a wider group of beneficiaries. SSA is planning to use a similar approach to test the effectiveness 
of mailed notices in increasing participation in Ticket to Work, a work support program for SSDI beneficiaries and SSI recipients. 
Exhibit 8. Example Reminder Letter

Social Security Administration

Social Security Disability Insurance

REMINDER TO REPORT EARNINGS

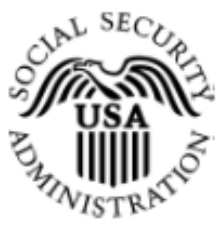

$\mathrm{MM} / \mathrm{DD} / 2020$

Your claim number: $\mathrm{XXXXXXXX}$

<irst and last name>

$<$ Address $1>$

$<$ Address $2>$

$<$ City, State ZIP $>$

Dear < First and Last Name $>$ :

If you are working - congratulations! We are writing to remind you that if you work, you must report your earnings to the Social Security Administration (SSA).

If you do not report your earnings, you could owe money back to SSA. To avoid this, report your earnings within two weeks of any of the following changes:

- You start or stop work, including self-employment

- Your duties, hours, or pay change from the last time you reported

If you cannot report within two weeks, report as soon as possible. Delays in reporting earnings lead to larger overpayments, which can total more than $\$ 9,000$.

\section{AVOID OVERPAYMENTS-REPORT YOUR EARNINGS NOW!}

Reporting earnings is fast and easy. Choose any of these four ways to report:

$\square$ Online: Log into your my Social Sectoity account at www.socialsecurity.gov/myaccount

Phone: Call 1-800-772-1213 (TTY 1-800-325-0778) between 7a.m. and 7p.m.,

Monday through Friday

E Mail: Fill in the enclosed "Earnings Reporting Form" and mail to <insert actual closest office address $>$

:?

In person: Visit your closest SSA office at <insert actual closest office address>

If you have a recent paystub, have that handy when you report. If you don't have a paystub-no problem! Report anything you know about your hours and pay.

Have questions? We are here to help

- If you would like to talk to a benefits counselor call 1-866-968-7842 (TTY 1-866-833-2967)

- Call SSA at 1-800-772-1213 (TTY 1-800-325-0778) 


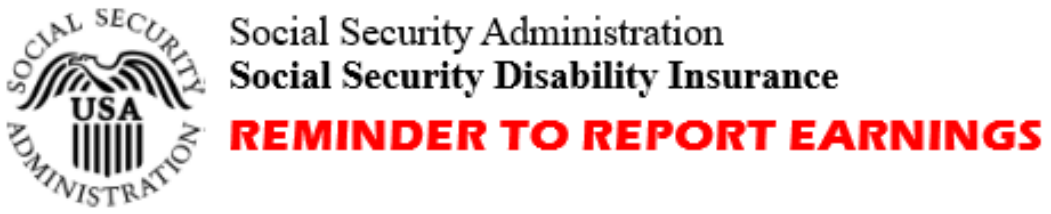

This notice is a reminder that if you work, you must report your earnings to the Social Security Administration (SSA).

\section{If you do not report your earnings, you could owe money back to SSA.}

To avoid this, report your earnings within two weeks of any of the following:

- You start or stop work, including self-employment

- Your duties, hours, or pay change from the last time you reported

If you cannot report within two weeks, report as soon as possible.

\section{AVOID OVERPAYMENTS-REPORT YOUR EARNINGS NOW!}

Choose one of these convenient ways to report:

Online: Log into your my Social Security account at

www.socialsecurity.gov/myaccount

Phone: Call 1-800-772-1213 (TTY 1-800-325-0778) between

7a.m. and 7p.m., Monday through Friday

Your claim number: $X X X X X X X X$

\section{? Have questions? We are here to help}

- If you would like to talk to a benefits counselor call 1-866-968-7842 (TTY 1-866-833-2967)

- Call SSA at 1-800-772-1213 (TTY 1-800-325-0778)

- Hablas Espanol? Llame al 1-800-772-1213 para hablar con un intérprete 


\section{Discussion}

Effective communication about earnings reporting requires that beneficiaries notice and open a document, locate and read the material on earnings reporting, decide to act, and act. Insights from behavioral economics point to several key issues that might prevent this: beneficiaries are infrequently notified or reminded of requirements, especially at points in time when that information is actionable; the content is not always clear, salient, and urgent; relevant text can be hard to find or otherwise does not effectively capture the reader's attention; and communications often do not emphasize how easy it is to report, what needs to be reported, deadlines for reporting, and the consequences of failing to report.

The four key steps to motivating beneficiary action are most effective when applied to the same document. Although there are examples of effective communication in each of the four categories spread across the seven documents we reviewed, none of the documents was individually effective in all four categories. For example, the Red Book is successful in several categories: it is organized so that beneficiaries can easily locate the material on returning to work, well-formatted to call attention to the conditions that necessitate reporting, and provides actionable information on how to report. However, the Red Book could improve on providing motivation to report and, importantly, is unlikely to be noticed and opened by most beneficiaries. The COLA letter, on the other hand, is very likely to be noticed and opened by beneficiaries, but is not formatted to help beneficiaries easily notice the information on earnings reporting, and does not use effective tools to encourage reporting.

This study analyzes one piece of the reporting process, the standard written communications SSA makes available to beneficiaries, and does not analyze several related parts of the reporting process. First, we analyzed only those communications that select SSA staff perceived to be most likely to be seen by working beneficiaries, which excluded communications from SSA partners. Second, we reviewed the standard documents available in English.

However, some beneficiaries are non-English speakers and these documents are only valuable to those beneficiaries if they are available in their language, if beneficiaries have a trusted person to translate the document, or if they are aware of and take advantage of SSA translation services. Similarly, beneficiaries' disabilities may preclude them from reading the standard communications. For example, blind beneficiaries may not be able to read the documents unless they are 508-compliant, a metric that we did not include in our analysis. Finally, we did not 
assess the reporting processes themselves. That is, we did not review the experience of reporting earnings to SSA online, via mail, by phone, or in person. This is an important but distinct part of the pathway to earnings reporting.

The behavioral economics literature indicates that low-cost changes to communications can lead to increased compliance. We developed an example reminder letter and postcard, informed by insights from behavioral economics, that SSA could send to SSDI beneficiaries to remind them about earnings reporting. Such communications could be rigorously tested in the context of SSDI earnings reporting. Cost-benefit analyses could be conducted to determine whether reminders-developed based on insights from behavioral economics-could be a cost-effective strategy to increase earnings reporting. Although mailing to the universe of SSDI beneficiaries can be costly, mailing to a targeted group of beneficiaries have the potential to effectively target reminders to those most at risk for unreported earnings and overpayments. Indeed, targeted earnings reporting reminders mailed to SSI beneficiaries generated an estimated $\$ 18$ in savings for every $\$ 1$ spent by SSA (Zhang et al. 2019). 


\section{References}

Allingham, M. G. and A. Sandmo. 1972. "Income Tax Evasion: A Theoretical Analysis." Journal of Public Economics 1(3-4): 323-338.

Ariel, B. 2012. "Deterrence and Moral Persuasion Effects on Corporate Tax Compliance: Findings from a Randomized Controlled Trial.” Criminology 50: 27-69.

Ariely, D. and K. Wertenbroch. 2002. "Procrastination, Deadlines, and Performance: SelfControl by Precommitment." Psychological Science 13(3): 219-224.

Baird, P., D. Cullinan, P. Landers, and L. Reardon. 2016. Nudges for Child Support: Applying Behavioral Insights to Increase Collections. Washington, DC: U.S. Department of Health and Human Services, Office of Planning, Research, and Evaluation. Available at: https://www.acf.hhs.gov/opre/resource/nudges-for-child-support-applying-behavioralinsights-to-increase-collections

Becker, G. 1968. "Crime and Punishment: An Economic Approach.” The Journal of Political Economy 76: 169-217.

Bertrand, M., S. Mullainathan, and E. Shafir. 2004. "A Behavioral-Economics View of Poverty." American Economic Review 94(2): 419-423.

Bettinger, E. P., B. T. Long, P. Oreopoulos, and L. Sanbonmatsu. 2009. "The Role of Simplification and Information in College Decisions: Results from the H\&R Block FAFSA Experiment.” Working Paper 15361. Cambridge, MA: National Bureau of Economic Research.

Bhargava, S. and D. Manoli. 2015. "Psychological Frictions and the Incomplete Take-Up of Social Benefits: Evidence from an IRS Field Experiment." American Economic Review 105(11): 3489-3529.

Blumenthal, M., C. Christian, and J. Slemrod. 2001. "Do Normative Appeals Affect Tax Compliance? Evidence from a Controlled Experiment in Minnesota." National Tax Journal 54: 125-136.

Boning, W. C., J. Guyton, R. H. Hodge, J. Slemrod, and U. Troiano. 2018. "Heard It Through The Grapevine: Direct and Network Effects of a Tax Enforcement Field Experiment." Working Paper 24305. Cambridge, MA: National Bureau of Economic Research.

Busso, M., J. Cristia, and S. Humpage. 2015. "Did You Get Your Shots? Experimental Evidence on the Role of Reminders." Journal of Health Economic, 44: 226-237. 
Cabinet Office Behavioural Insights Team. 2012. Applying Behavioural Insights to Reduce Fraud, Error and Debt. London, UK. Available at: https://assets.publishing.service.gov.uk/government/uploads/system/uploads/attachment data/file/60539/BIT_FraudErrorDebt_accessible.pdf

Chirico, M., R. Inman, C. Loeffler, J. MacDonald, and H. Sieg. 2019. "Deferring Property Tax Delinquency in Philadelphia: An Experimental Evaluation of Nudge Strategies." Working Paper 23243. Cambridge, MA: National Bureau of Economic Research.

Chojnacki, G., J. Deutsch, S. Amin, I. Perez-Johnson, M. Darling, and J. Lefkowitz. 2017. "Pilot OSHA Citation Process Increases Employer Responsiveness.” DOL Behavioral Interventions Project Brief. Princeton, NJ: Mathematica Policy Research.

Cialdini, R. B., C. A. Kallgren, and R. R. Reno. 1991. "A Focus Theory of Normative Conduct." Advances in Experimental Social Psychology 24: 201-234.

Darling, M., C. O’Leary, I. Perez-Johnson, J. Lefkowitz, K. Kline, B. Damerow, R. Eberts, S. Amin, and G. Chojnacki. 2017. "Using Behavioral Insights to Improve Take-Up of a Reemployment Program: Trial Design and Findings.” DOL Behavioral Interventions Project Brief. Princeton, NJ: Mathematica Policy Research.

Damgaard, M. T. and C. Gravert. 2018. The Hidden Costs of Nudging: Experimental Evidence from Reminders in Fundraising. Journal of Public Economics 157: 15-26.

Dechausay, N., C. Anzelone, and L. Reardon. 2015. "The Power of Prompts: Using Behavioral Insights to Encourage People to Participate." OPRE Report 2015-75. Washington, DC: U.S. Department of Health and Human Services, Office of Planning, Research, and Evaluation.

Dynarski, S. M. and J. E. Scott-Clayton. 2006. "The Cost of Complexity in Federal Student Aid: Lessons from Optimal Tax Theory and Behavioral Economics.” Working Paper w12227. Cambridge, MA: National Bureau of Economic Research.

Farrell, M., J. Smith, L. Reardon, and E. Obara. 2016. "Framing the Message: Using Behavioral Economics to Engage TANF Recipients.” OPRE Report 2016-02. Washington, DC: U.S. Department of Health and Human Services, Office of Planning, Research, and Evaluation.

Frederick, S., G. Loewenstein, and T. O’Donoghue. 2002. "Time Discounting and Time Preference: A Critical Review." Journal of Economic Literature 40(2): 351-401.

Gillitzer, C. and M. Sinning. 2018. "Nudging Businesses to Pay Their Taxes: Does the Timing of Reminder Letters Matter?" Discussion Paper Series 11599. Bonn, Germany: IZA Institute of Labor Economics. 
Glosser, A., D. Cullinan, and E. Obara. 2016. "Simplify, Notify, Modify: Using Behavioral Insights to Increase Incarcerated Parents' Requests for Child Support Modifications." OPRE Report 2016-43. Washington, DC: U.S. Department of Health and Human Services, Office of Planning, Research, and Evaluation.

Government Accountability Office. 2015. "SSA Could Do More to Prevent Overpayments or Incorrect Waivers to Beneficiaries." GAO-16-34, a report to the Subcommittee on Social Security, Committee on Ways and Means, House of Representatives. Available at: https://www.gao.gov/assets/680/673426.pdf

Gubits, D., M. Derr, J. Berk, A. Person, D. Stapleton, D. Hoffman, S. Bell, R. Cook, and D. Wittenburg. 2013. "BOND Implementation and Evaluation: Stage 2 Early Assessment Report." Deliverable 24a.2. Cambridge, MA: Abt Associates.

Guyton, J., D. S. Manoli, B. Schafer, and M. Sebastiani. 2016. "Reminders \& Recidivism: Evidence from Tax Filing and EITC Participation Among Low-Income Nonfilers." Working Paper 21904. Cambridge, MA: National Bureau of Economic Research.

Hallsworth, M. 2014. "The Use of Field Experiments to Increase Tax Compliance." Oxford Review of Economic Policy 30(4): 658-679.

Hallsworth, M., J. A. List, R. D. Metcalfe, and I. Vlaev. 2017. "The Behavioralist as Tax Collector: Using Natural Field Experiments to Enhance Tax Compliance." Journal of Public Economics 148: 14-31.

Hock, H., M. Levere, K. Fortson, and D. Wittenburg. 2019. "Lessons from Pilot Tests of Recruitment for the Promoting Opportunity Demonstration.” Issue Brief. Washington, DC: Mathematica Policy Research.

Hoffman, D., S. Croake, D. R. Mann, D. Stapleton, P. Anand, C. Jones, J. Geyer, D. Gubits, S. Bell, A. McGuirk, D. Wittenburg, D. Wright, A. Sukasih, D. Judkins, and M. Sinclair. 2017. "BOND Implementation and Evaluation: 2016 Stage 1 Interim Process, Participation, and Impact Report.” Deliverable 24c2.1. Cambridge, MA: Abt Associates.

Hoffman, D., B. Fischer, J. T. Jones, A. McGuirk, and M. Loewenberg. 2019. "Work-Related Overpayments to Social Security Disability Insurance Beneficiaries: Prevalence and Descriptive Statistics." Social Security Bulletin 79(2): 65-83.

Iyer, G. S., P. M. Reckers, and D. L. Sanders. 2010. "Increasing Tax Compliance in Washington State: A Field Experiment." National Tax Journal 63(1): 7-32.

John, P. and T. Blume. 2018. "How Best to Nudge Taxpayers? The Impact of Message Simplification and Descriptive Social Norms on Payment Rates in a Central London Local Authority." Journal of Behavioral Public Administration 1(1). 
Johnson, E. J., S. B. Shu, B. G. Dellaert, C. Fox, D. G. Goldstein, G. Häubl, R. P. Larrick, J. W. Payne, E. Peters, and D. Schkade. 2012. "Beyond Nudges: Tools of a Choice Architecture.” Marketing Letters 23(2): 487-504.

Kahneman, D. 2011. Thinking, Fast and Slow. New York, NY: Farrar, Straus, and Giroux.

Karlan, D., M. McConnell, S. Mullainathan, and J. Zinman. 2016. "Getting to the Top of Mind: How Reminders Increase Saving.” Management Science 62(12): 3393-3411.

Karlsson, N., G. Loewenstein, and D. Seppi. 2009. "The Ostrich Effect: Selective Attention to Information." Journal of Risk and Uncertainty 38(2): 95-115.

Kettle, S., M. Hernandez, S. Ruda, and M. Sanders. 2016. "Behavioral Interventions in Tax Compliance: Evidence from Guatemala.” Policy Research Working Paper 7690. Washington, DC: The World Bank.

Kleven, H. J., M. B. Knudsen, C. T. Kreiner, S. Pedersen, and E. Saez. 2011. "Unwilling or Unable to Cheat? Evidence from a Tax Audit Experiment in Denmark." Econometrica 79(3): 651-692.

Kregel, J. 2018. “A Qualitative Study of Employment Experiences of SSDI Beneficiaries After Receipt of an Overpayment.” DRC Working Paper 2018-06. Washington, DC: Mathematica Policy Research.

Laibson, D. 1997. "Golden Eggs and Hyperbolic Discounting." The Quarterly Journal of Economics 112(2): 443-478.

Larkin, C., M. Sanders, I. Andresen, and F. Algate. 2019. “Testing Local Descriptive Norms and Salience of Enforcement Action: A Field Experiment to Increase Tax Collection." Journal of Behavioral Public Administration 2(1): 1-11.

Madrian, B. C. 2014. "Applying Insights from Behavioral Economics to Policy Design.” Annual Review of Economics 6(1): 663-688.

Milkman, K. L., J. Beshears, J. J. Choi, D. Laibson, and B. C. Madrian. 2011. "Using Implementation Intentions Prompts to Enhance Influenza Vaccination Rates." Proceedings of the National Academy of Sciences 108(26): 10415-10420.

O’Day, B., F. Martin, H. Burak, G. Freeman, K. Feeney, G. Lim, E. Kelley, and K. Morrison. 2016. "Employment Experiences of Young Adults and High Earners Who Receive Social Security Disability Benefits: Findings from Semistructured Interviews." Report. Washington, DC: Mathematica Policy Research.

Ortega, D. and P. Sanguinetti. 2013. "Deterrence and Reciprocity Effects on Tax Compliance: Experimental Evidence from Venezuela." CAF Working Paper 2013-08. Caracas, Venezuela: Development Bank of Latin America. 
Rabin, M. 1993. "Incorporating Fairness into Game Theory and Economics." The American Economic Review 83(5): 1281-1302.

Richburg-Hayes, L., C. Anzelone, and N. Dechausay. 2017. "Nudging Change in Human Services: Final Report of the Behavioral Interventions to Advance Self-Sufficiency (BIAS) Project." OPRE Report 2017-23. Washington, DC: U.S. Department of Health and Human Services, Office of Planning, Research, and Evaluation.

Slemrod, J., M. Blumenthal, and C. Christian. 2001. "Taxpayer Response to an Increased Probability of Audit: Evidence from a Controlled Experiment in Minnesota." Journal of Public Economics 79(3): 455-483.

Thaler, R. H. and C. R. Sunstein. 2009. Nudge: Improving Decisions About Health, Wealth, and Happiness. London, UK: Penguin Books.

Torgler, B. 2012. "A Field Experiment on Moral Suasion and Tax Compliance Focusing on Under-Declaration and Over-Deduction." Brisbane, Australia: Queensland University of Technology, School of Economics and Finance.

Tversky, A. and D. Kahneman. 1991. "Loss Aversion in Riskless Choice: A ReferenceDependent Model.” Quarterly Journal of Economics 106(4): 1039-1061.

U.S. Social Security Administration. 2018. "Social Security Administration Agency Financial Report, Fiscal Year 2018." Washington, DC. Available at: https://www.ssa.gov/finance/2018/Full\%20FY\%202018\%20AFR.pdf

U.S. Social Security Administration, Office of the Inspector General. 2015. Overpayments in the Social Security Administration's Disability Program - A 10-Year Study. Washington, DC. Available at: https://oig.ssa.gov/sites/default/files/audit/full/pdf/A-01-14-24114.pdf

U.S. Social Security Administration, Office of the Inspector General. 2018. "Incorrect Payments to Disabled Beneficiaries Who Return to Work." Washington, DC. Available at: https://oig.ssa.gov/audits-and-investigations/audit-reports/A-07-17-50131

U.S. Social Security Administration. 2019. "Social Security Administration Agency Financial Report, Fiscal Year 2019." Washington, DC. Available at: https://www.ssa.gov/finance/2019/Full\%20FY\%202019\%20AFR.pdf

Zhang, C. W., J. Hemmeter, J. B. Kessler, R. D. Metcalfe, and R. Weathers. 2019. "Nudging Timely Wage Reporting: Field Experimental Evidence from the United States Supplemental Security Income Program.” Working Paper. Washington, DC: General Services Administration, Office of Evaluation Sciences. 


\section{RECENT WORKING PAPERS FROM THE CENTER FOR RETIREMENT RESEARCH AT BOSTON COLLEGE}

How Accurate Are Retirees' Assessments of Their Retirement Risk? Wenliang Hou, July 2020

Is Nontraditional Work at Older Ages Associated with Better Retirement Security? Matthew S. Rutledge and Gal Wettstein, July 2020

New Insights on Self-Employment of Older Adults in the United States Joelle Abramowitz, July 2020

What Jobs Do Employers Want Older Workers to Do?

Alicia H. Munnell, Gal Wettstein, and Abigail N. Walters, June 2020

Technological Innovation and Labor Income Risk

Leonid Kogan, Dimitris Papanikolaou, Lawrence D. W. Schmidt, and Jae Song, June 2020

Are Older Nontraditional Workers Able to Find Health and Retirement Coverage? Matthew S. Rutledge, March 2020

Employer Perceptions of Older Workers - Surveys from 2019 and 2006 Alicia H. Munnell and Gal Wettstein, March 2020

Are Homeownership Patterns Stable Enough to Tap Home Equity?

Alicia H. Munnell, Abigail N. Walters, Anek Belbase, and Wenliang Hou, January 2020

The Impact of the Minimum Wage on DI Participation

Gary V. Engelhardt, January 2020

Scheduling Uncertainty and Employment of Young Adults with Disabilities

Dara Lee Luca and Purvi Sevak, January 2020

Wages and the Value of Nonemployment

Simon Jäger, Benjamin Schoefer, Samuel Young, and Josef Zweimüller, January 2020

The Equilibrium and Spillover Effects of Early Retirement

Simon Jäger, Benjamin Schoefer, and Josef Zweimüller, January 2020

Measuring Racial/Ethnic Retirement Wealth Inequality

Wenliang Hou and Geoffrey T. Sanzenbacher, January 2020

All working papers are available on the Center for Retirement Research website (https://crr.bc.edu) and can be requested bye-mail (crr@bc.edu) or phone (617-552-1762). 